\title{
PHYSIOLOGICAL EFFECTS OF MECHANICAL EXSUFFLATION \\ ON EXPERIMENTAL OBSTRUCTIVE BREATHING IN HUMAN SUBJECTS ${ }^{2}$
}

\author{
By REUBEN M. CHERNIACK, ${ }^{2}$ CHARLES A. GORDON, ${ }^{3}$ AND FRED DRIMMER \\ (From the Department of Medicine, College of Physicians and Surgeons, Columbia University \\ and the Goldwater Memorial Hospital, Columbia Division, New York, and the \\ Presbyterian Hospital, New York, N. Y.)
}

(Submitted for publication June 5, 1952; accepted September 12, 1952)

The increased physical effort necessary to breathe through a constricted orifice results in an instantaneous and uncomfortable sensation of dyspnea. The immediate sensation of difficulty in breathing is aroused by proprioceptive reflexes. The duration of inspiration and expiration becomes markedly prolonged, $(1,2)$ and in spite of the increased work entailed, the peak volume flow rates diminish. The minute ventilation has been shown by Cain and Otis (1) to decrease. Haldane and Priestley (3) and others $(1,4)$ also noted that hypoxia and retention of carbon dioxide develops due to the prolonged duration of the respiratory cycle and reduced alveolar ventilation, resulting from obstructed breathing. Furthermore, a lower or more negative intrapleural pressure develops during the inspiratory phase when breathing against a resistance. The pathological consequences of obstructed breathing, namely pulmonary congestion, have been demonstrated in animals by Moore and Binger $(4,5)$ and Barach and his associates $(6-8)$.

During the initial studies on the physiological effects of exsufflation, the principle of which is described in Methods, it was noted that the physical effort required to breathe against a resistance introduced at the mouth was markedly diminished $(9,10)$. Since exsufflation appeared subjectively to relieve dyspnea it was of interest to study its physiological effect on experimentally produced obstructed breathing in normal human subjects. The purpose of this paper is to show the effect of exsufflation on 1) inspiratory and expiratory volume flow rates, 2) alveolar $\mathrm{pCO}_{2}$ and $\mathrm{pO}_{2}$, and 3) peripheral venous pressure and intraoral pressure during obstructed breathing.

\footnotetext{
1 Aided by a grant from the National Foundation for Infantile Paralysis.

2 Present address University of Manitoba, Winnipeg, Manitoba, Canada.

3 Present address Dalhousie University, Halifax, Nova Scotia, Canada.
}

\section{METHODS}

Two mechanical methods of simulating a cough in man were originally devised by Barach and his coworkers (9-11) as a means of eliminating secretions in patients who are unable to cough effectively. One of these methods, exsufflation, i.e., rapid movement of air from the lungs, is accomplished by enclosing the body of the patient in a conventional tank respirator. A negative intra-tank pressure of $40 \mathrm{~mm}$. $\mathrm{Hg}$, developed over a two-second period by a motor blower unit attached to the respirator, is followed by a rapid return to atmospheric pressure in 0.06 seconds by means of a swift-opening valve. The termination of the intra-tank pressure in 0.06 seconds removes a force which tends to keep the lungs inflated in other forms of intermittent pressure breathing where there is a gradually descending expiratory pressure curve (see Figure 1). The rate of exsufflation can be adjusted to produce any desired minute ventilation. This procedure has produced peak expiratory volume flow rates measuring 60 per cent of those

\section{PRESSURE CURVES WITH RESPIRATOR AND EXSUFFLATOR}

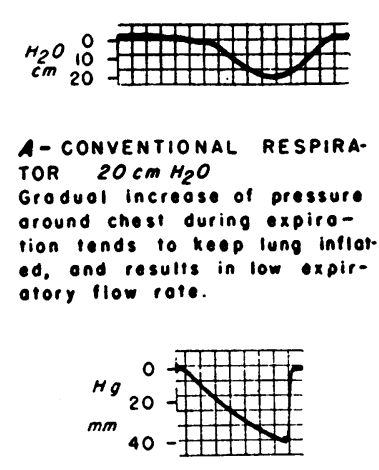

$\theta$ - EXSUfFLATOR $40 \mathrm{~mm} \mathrm{mg}$ Sudden increose of pressure oround chest during expiration cromoves force lending to keep lung infloted, ond results in high expirotory flow rate.

Fig. 1

Vertical lines represent 0.2 seconds. 
found in the most vigorous cough obtainable in normal human subjects $(9,11)$.

Young healthy volunteers who exhibited no evidence of cardio-respiratory disease participated in this study. The subjects were placed in the modified tank respirator, and after the breathing pattern had become regular, control tracings were obtained on a recording spirometer in which the resistance was minimal. Immediately after the control period, obstructed breathing was produced by the introduction of a $3 \mathrm{~mm}$. orifice at the mouthpiece for 6 minutes. During the latter three minutes of this period of obstructed breathing exsufflation was applied at a rate of 9 times per minute.

Determinations of inspiratory and expiratory volume flow rates, alveolar $\mathrm{pCO}_{2}$ and $\mathrm{pO}_{2}$, peripheral venous pressure, and intraoral pressure were performed during normal quiet breathing, after the three minute period of obstructed breathing, and at the end of the period of exsufflation.

The spirographic tracings obtained on a high speed drum during normal breathing and obstructed breathing before and after the addition of exsufflation were analyzed in terms of volume of air movement per unit time. The inspiratory and expiratory volume flow rates were derived from these data and plotted graphically.

End expiratory samples of gas were collected and analyzed by the micro-Scholander method. From these data, the alveolar $\mathrm{pO}_{2}$ and $\mathrm{pCO}_{2}$ were calculated.

Peripheral venous pressure was recorded from the antecubital vein through an 18-gauge needle attached to a differential Statham strain gauge which was exposed to the intra-tank pressure. Intermittent infusion of heparinized saline assured the fluidity of the system and prevented clotting at the needle. Mean venous pressure was determined by planimetric integration of the area under the pressure curve.

The intraoral pressure tracings were obtained with a 20 -gauge needle inserted into the mouthpiece and recorded by a Statham strain gauge exposed to the intratank pressure in a manner similar to that of the venous pressure.

The peripheral venous pressure was found to rise with an increase in the mean applied intrapulmonary pressure by Barach and his co-workers $(8,12)$, Otis, Rahn and Fenn (13) and Barach, Fenn, Ferris and Schmidt (14). Furthermore, Elisberg, Goldberg and Snider (15) noted a positive correlation between intraoral pressures and intrapleural pressures. Under static conditions at the end of inspiration or expiration, pleural pressure equals mouth pressure minus the pressure resulting from lung elasticity. During inspiration or expiration, these relationships are altered by the pressures which are required to overcome the dynamic resistances involved in moving gas and deforming tissue. The measurements of the variations in peripheral venous pressure and intraoral pressure thus served to reflect similar directional changes in the intrapleural pressure.
TABLE I

Obstructed breathing: the reversal of altered inspiratory volume flow rate by exsufflation

\begin{tabular}{|c|c|c|c|c|}
\hline \multicolumn{5}{|c|}{ Maximum volume flow rate } \\
\hline \multirow{2}{*}{$\begin{array}{l}\text { Case } \\
\text { No. }\end{array}$} & \multirow{2}{*}{$\underset{\text { breathing }}{\text { Normal }}$} & \multirow{2}{*}{$\begin{array}{l}\text { Obstructed } \\
\text { breathing }\end{array}$} & \multicolumn{2}{|c|}{$\begin{array}{l}\text { Obstructed breathing and } \\
\text { exsufflation }\end{array}$} \\
\hline & & & & $\begin{array}{c}\text { Change from } \\
\text { obstructed } \\
\text { breathing }\end{array}$ \\
\hline $\begin{array}{c}1 \\
2 \\
3 \\
4 \\
5 \\
6 \\
7 \\
8 \\
\text { Aver. }\end{array}$ & $\begin{array}{c}c c . / \text { sec. } \\
605 \\
649 \\
605 \\
476 \\
843 \\
476 \\
476 \\
605 \\
592\end{array}$ & $\begin{array}{c}c c . / \mathrm{sec} . \\
346 \\
605 \\
519 \\
432 \\
908 \\
345 \\
432 \\
435 \\
503\end{array}$ & $\begin{array}{c}c c . / s e c . \\
951 \\
735 \\
908 \\
692 \\
1103 \\
692 \\
476 \\
950 \\
813\end{array}$ & $\begin{array}{l}\text { per cent } \\
+175 \\
+20 \\
+75 \\
+60 \\
+21 \\
+101 \\
+10 \\
+118 \\
+72\end{array}$ \\
\hline
\end{tabular}

\section{RESULTS}

In all subjects the sensation of dyspnea experienced when breathing through a $3 \mathrm{~mm}$. orifice was relieved by exsufflation.

The added resistance to breathing resulted in a 15 per cent decrease in the peak inspiratory volume flow rate. The use of the exsufflator produced a striking increase in volume flow rates averaging 72 per cent above the rate observed during obstructed breathing. This reversal of altered inspiratory volume flow rate is shown in Table I. While breathing against a resistance, the peak expiratory volume flow rate decreased, averaging 28 per cent of that observed during nor-

TABLE II

Obstructed breathing: the reversal of altered expiratory volume flow rate by exsufflation

\begin{tabular}{|c|c|c|c|c|}
\hline \multicolumn{5}{|c|}{ Maximum volume flow rate } \\
\hline \multirow{2}{*}{$\begin{array}{l}\text { Case } \\
\text { No. }\end{array}$} & \multirow{2}{*}{$\underset{\text { breathing }}{\text { Normal }}$} & \multirow{2}{*}{$\begin{array}{l}\text { Obstructed } \\
\text { breathing }\end{array}$} & \multicolumn{2}{|c|}{$\begin{array}{c}\text { Obstructed breathing and } \\
\text { exsufflation }\end{array}$} \\
\hline & & & & $\begin{array}{c}\text { Change from } \\
\text { obstructed } \\
\text { breathing }\end{array}$ \\
\hline $\begin{array}{c}1 \\
2 \\
3 \\
4 \\
5 \\
6 \\
7 \\
8 \\
\text { Aver. }\end{array}$ & $\begin{array}{c}c c . / \mathrm{sec} . \\
605 \\
778 \\
519 \\
778 \\
584 \\
519 \\
648 \\
519 \\
619\end{array}$ & $\begin{array}{c}c c . / \mathrm{sec} . \\
432 \\
432 \\
346 \\
432 \\
519 \\
432 \\
476 \\
480 \\
444\end{array}$ & $\begin{array}{r}c c . / s e c . \\
692 \\
432 \\
519 \\
519 \\
1492 \\
345 \\
385 \\
825 \\
651\end{array}$ & $\begin{array}{r}\text { per cent } \\
+60 \\
0 \\
+50 \\
+20 \\
+187 \\
-20 \\
-20 \\
+72 \\
+43\end{array}$ \\
\hline
\end{tabular}




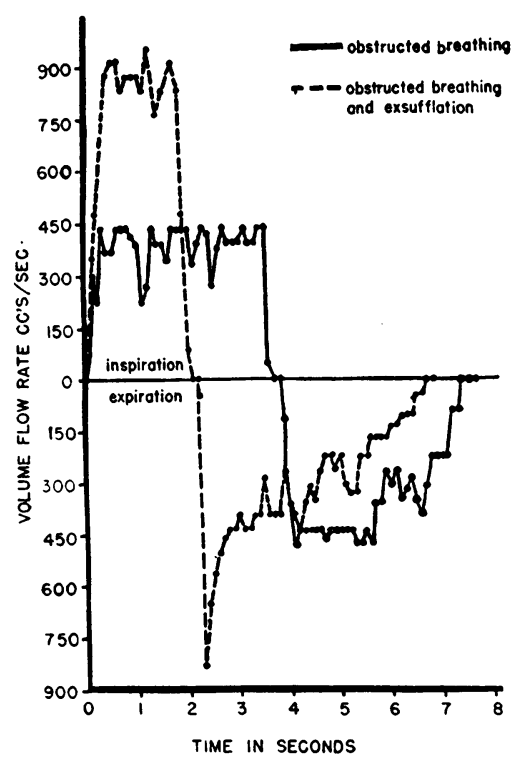

OBSTRUCTED BR EATHINGI EFFECT OF EXSUFFLATION ON VOLUME FLOW RATE

$\begin{array}{ccc}\text { Maximum Volume Flow Role } & \text { Inspiration } & \text { Explration } \\ \begin{array}{c}\text { Obstructed Breathing } \\ \begin{array}{c}\text { Obstructed Breathing } \\ \text { With Exsufflation }\end{array}\end{array} & 435 \mathrm{cc} & 480 \mathrm{cc} \\ & 950 \mathrm{cc} & 825 \mathrm{cc}\end{array}$

FIG. 2

mal expiration. A rise in expiratory volume flow rate of 43 per cent above the obstructed breathing level was induced by exsufflation, as seen in Table II. When the expiratory volume flow rate was plotted against time, as is demonstrated in Figure 2 , the maximal increase in flow rate was found to occur at the onset of expiration.

The average tidal volume during normal breathing was $581 \mathrm{cc}$., and fell to $485 \mathrm{cc}$. or by 16 per cent when breathing against a resistance. As is seen in Table III, when exsufflation was added the average tidal volume was $1,074 \mathrm{cc}$., a rise of 85 per

TABLE III

Tidal air volume

\begin{tabular}{c|c|c|c}
\hline \hline Case No. & $\begin{array}{c}\text { Normal } \\
\text { breathing }\end{array}$ & $\begin{array}{c}\text { Obstructed } \\
\text { breathing }\end{array}$ & $\begin{array}{c}\text { Obstructed } \\
\text { breathing and } \\
\text { exsufflation }\end{array}$ \\
\cline { 2 - 3 } 1 & $c c$. & $c c$. & $c c$. \\
2 & 735 & 395 & 1,513 \\
3 & 393 & 432 & 1,211 \\
4 & 670 & 660 & 1,103 \\
5 & 411 & 419 & 886 \\
6 & 751 & 778 & 935 \\
7 & 389 & 246 & 1,124 \\
8 & 468 & 535 & 951 \\
Aver. & 432 & 412 & 876 \\
\hline
\end{tabular}

cent over that in normal breathing and 121 per cent over that during obstructed breathing.

The average minute ventilation of $7,431 \mathrm{cc}$. fell to $5,328 \mathrm{cc}$. or by 27 per cent during obstructed breathing. During exsufflation, minute volume was $9,644 \mathrm{cc}$. or 29 per cent higher than during normal breathing, and 81 per cent above that during obstructed breathing. This is shown in Table IV.

TABLE IV

Minute ventilation, $c c . / \min$.

\begin{tabular}{c|c|c|c}
\hline \hline Case No. & $\begin{array}{c}\text { Normal } \\
\text { breathing }\end{array}$ & $\begin{array}{c}\text { Obstructed } \\
\text { breathing }\end{array}$ & $\begin{array}{c}\text { Obstructed } \\
\text { breathing and } \\
\text { exsufflation }\end{array}$ \\
\hline & cc. min. & \\
1 & 9,555 & 6,320 & 13,617 \\
2 & 6,288 & 4,616 & 10,899 \\
3 & 8,710 & 7,920 & 9,927 \\
4 & 6,165 & 6,447 & 7,974 \\
5 & 9,012 & 7,780 & 8,505 \\
6 & 6,184 & 4,182 & 10,016 \\
7 & 7,488 & 6,420 & 8,559 \\
8 & 6,048 & 4,944 & 7,884 \\
Aver. & 7,431 & 5,328 & 9,644 \\
\hline
\end{tabular}

In seven subjects the average alveolar $\mathrm{pCO}_{2}$ rose $4.8 \mathrm{~mm}$. $\mathrm{Hg}$ or 13 per cent (range 5.4 to 29.9 per cent) during obstructed breathing. The addition of exsufflation resulted in a reversal of $\mathrm{CO}_{2}$ tension toward, and in some instances below, the control level. These findings are illustrated in Figure 3. The average alveolar $\mathrm{pCO}_{2}$ produced by exsufflation was $8.0 \mathrm{~mm}$. Hg or 19 per cent (range 11.2 to 31.4 per cent) below that present during obstructed breathing.

During obstructed breathing, the alveolar $\mathrm{pO}_{2}$ fell an average of $9.7 \mathrm{~mm}$. $\mathrm{Hg}$ or 9.1 per cent

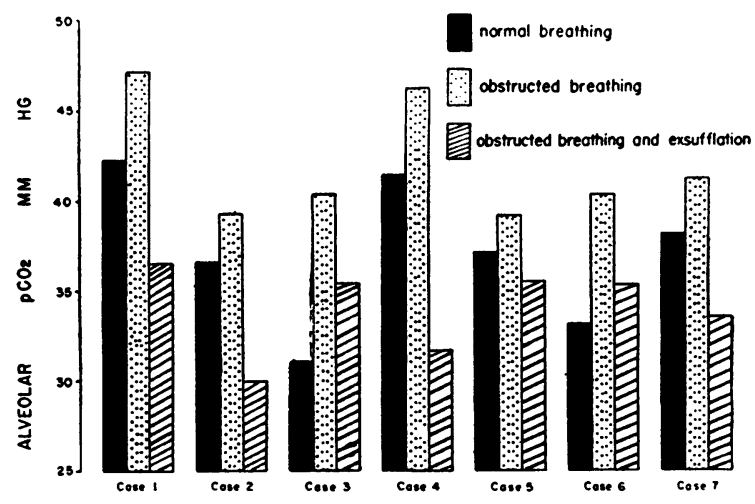

OBSTRUCTED BREATHING: THE EFFECT OF EXSUFFLATION ON ELEVATED ALVEOLAR DCOZ

Fig. 3 


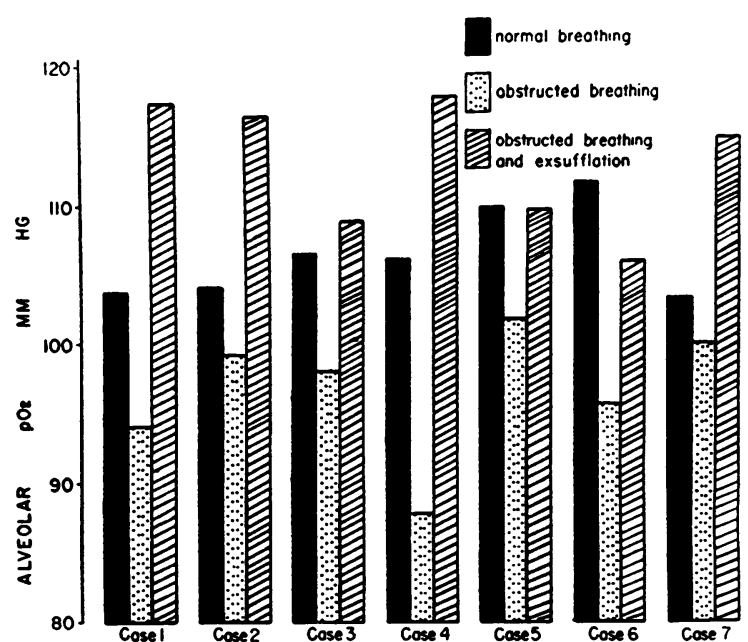

OBSTRUCTED BREATHING: EFFECT OF EXSUFFLATION ON LOWERED ALVEQLAR POZ

Fig. 4

(range 3.2 to 17.3 per cent) below the control values in seven subjects. Following 3 minutes of exsufflation the $\mathrm{pO}_{2}$ increased an average of 12.4 $\mathrm{mm} . \mathrm{Hg}$ or 16.9 per cent (range 7.8 to 34.2 per cent) above that observed with obstructed breathing. This is graphically illustrated in Figure 4.

The peripheral venous pressure was determined in eight subjects and recorded relative to the tank pressure. The average mean venous pressure fell $7 \mathrm{~mm} . \mathrm{H}_{2} \mathrm{O}$ when a resistance to breathing was introduced. The addition of exsufflation resulted in an average rise of $20 \mathrm{~mm} . \mathrm{H}_{2} \mathrm{O}$ above this level and $13 \mathrm{~mm} . \mathrm{H}_{2} \mathrm{O}$ above the normal breathing level, as seen in Table V. During the inspiratory phase an average drop of $6 \mathrm{~mm} . \mathrm{H}_{2} \mathrm{O}$ (range 3 to 16 $\mathrm{mm}$.) was noted when the obstruction to breathing was added. The minimal level recorded during exsufflation was $12 \mathrm{~mm} . \mathrm{H}_{2} \mathrm{O}$ above the value obtained during obstructed breathing and 6 $\mathrm{mm} . \mathrm{H}_{2} \mathrm{O}$ above the normal breathing value. A

TABLE $V$

Obstructed breathing: the reversal of altered mean venous pressure by exsufflation

\begin{tabular}{c|c|c|c}
\hline \multicolumn{4}{c}{$\begin{array}{c}\text { Mean venous pressure } \\
\text { (mm. H, })\end{array}$} \\
\hline \multirow{3}{*}{ Case No. } & $\begin{array}{c}\text { Normal } \\
\text { breathing }\end{array}$ & $\begin{array}{c}\text { Obstructed } \\
\text { breathing }\end{array}$ & $\begin{array}{c}\text { Obstructed } \\
\text { breathing and } \\
\text { exsufflation }\end{array}$ \\
\hline 1 & 83 & 77 & 87 \\
& 72 & 69 & 79 \\
2 & 106 & 100 & 112 \\
& 81 & 72 & 101 \\
3 & 98 & 79 & 90 \\
4 & 99 & 91 & 99 \\
5 & 97 & 92 & 113 \\
& 70 & 63 & 78 \\
6 & 64 & 52 & 64 \\
7 & 78 & 73 & 110 \\
8 & 74 & 72 & 84 \\
Aver. & 68 & 62 & 106 \\
& 78 & 71 & 108 \\
& 82 & 75 & 95 \\
\hline
\end{tabular}

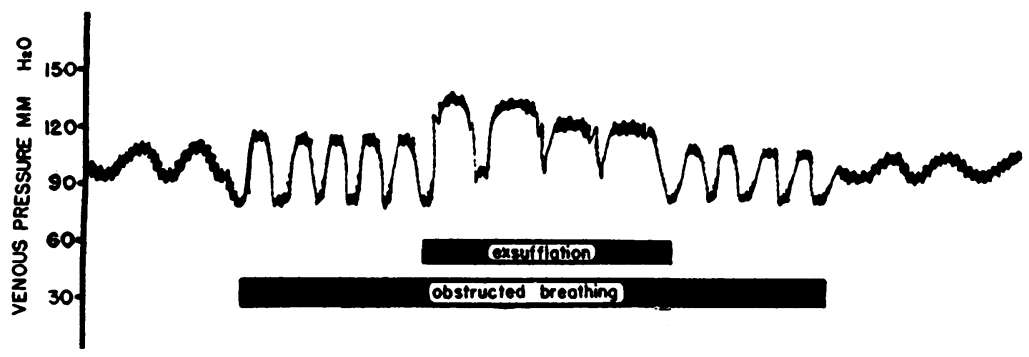

OBSTRUCTED BREATHING: EFFECT OF EXSUFFLATION ON VENOUS PRESSURE

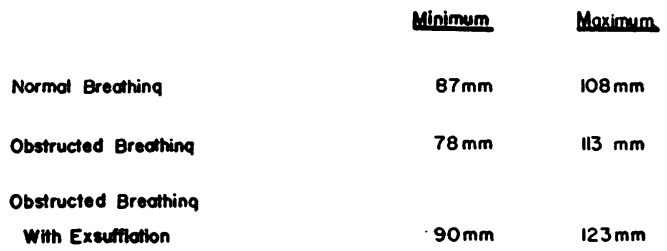

FIG. 5

The lowering of the inspiratory venous pressure produced by obstructive breathing is abolished during exsufflation. 
TABLE VI

Obstructed breathing: the reversal of altered intraoral pressure by exsufflation

\begin{tabular}{|c|c|c|c|c|c|c|}
\hline \multirow{3}{*}{ Case No. } & \multicolumn{6}{|c|}{$\begin{array}{c}\text { Intraoral pressure } \\
\left(\mathrm{mm} . \mathrm{H}_{2} \mathrm{O}\right)\end{array}$} \\
\hline & \multicolumn{3}{|c|}{ Minimal level recorded } & \multicolumn{3}{|c|}{ Maximal level recorded } \\
\hline & $\underset{\text { breathing }}{\text { Normal }}$ & $\begin{array}{c}\text { Obstructed } \\
\text { breathing }\end{array}$ & $\begin{array}{c}\text { Obstructed } \\
\text { breathing and } \\
\text { exsufffation }\end{array}$ & $\underset{\text { breathing }}{\text { Normal }}$ & $\begin{array}{c}\text { Obstructed } \\
\text { breathing }\end{array}$ & $\begin{array}{c}\text { Obstructed } \\
\text { breathing and } \\
\text { exsuffatation }\end{array}$ \\
\hline $\begin{array}{c}1 \\
2 \\
3 \\
4 \\
5 \\
6 \\
\text { Aver. }\end{array}$ & $\begin{array}{l}-6 \\
-2 \\
-3 \\
-2 \\
-5 \\
-5 \\
-4\end{array}$ & $\begin{array}{l}-43 \\
-84 \\
-36 \\
-45 \\
-52 \\
-87 \\
-58\end{array}$ & $\begin{array}{l}+4 \\
+4 \\
+6 \\
+3 \\
+2 \\
+1 \\
+3\end{array}$ & $\begin{array}{c}0 \\
+1 \\
0 \\
+1 \\
+2 \\
0 \\
+0.6\end{array}$ & $\begin{array}{l}+58 \\
+66 \\
+36 \\
+31 \\
+35 \\
+53 \\
+47\end{array}$ & $\begin{array}{l}+112 \\
+139 \\
+143 \\
+149 \\
+143 \\
+124 \\
+135\end{array}$ \\
\hline
\end{tabular}

representative venous pressure tracing, shown in Figure 5, reveals that the lowered negative pressure during inspiration is no longer present when exsufflation is added.

An average negative intraoral pressure of 58 $\mathrm{mm} . \mathrm{H}_{2} \mathrm{O}$ relative to the tank pressure was recorded when breathing through a $3 \mathrm{~mm}$. orifice. The addition of exsufflation resulted in a striking reversal of this negative intraoral pressure. From data presented in Table VI and Figure 6 the lowest pressure observed with exsufflation was plus $1 \mathrm{~mm} . \mathrm{H}_{2} \mathrm{O}$.

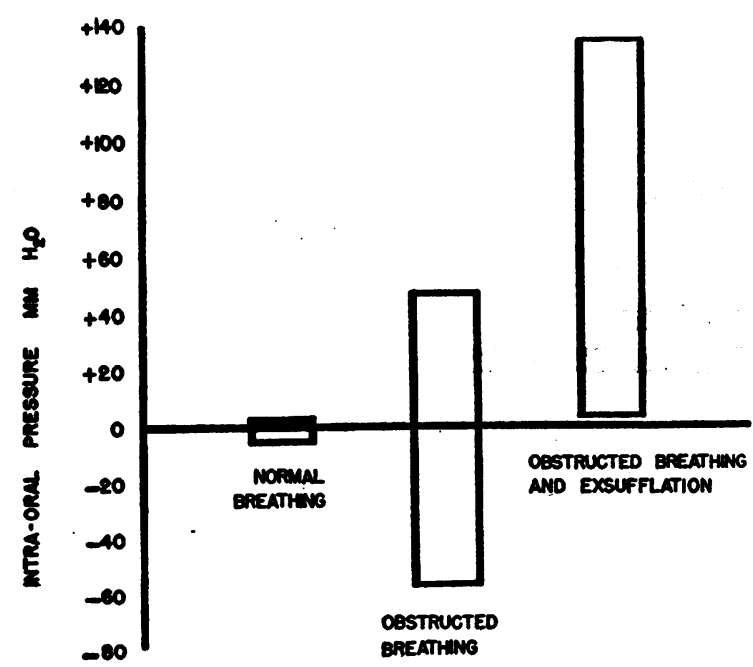

COSTRUCTED BREATHMG: EFFECT OF EXSUFFLATION ON WTRRA-ORAL PRESSURE

Fig. 6

The lowering of the inspiratory intraoral pressure produced by obstructed breathing is abolished during exsufflation.

\section{DISCUSSION}

An attempt has been made in this study to simulate as much as possible the obstructive component present in clinical conditions which constrict the larynx, trachea or bronchi, including tumor mass, foreign body, or the thick viscid bronchial secretions associated with bronchial asthma, bronchiectasis and the bronchospastic type of pulmonary emphysema. In normal respiration the bronchial tree lengthens and dilates during inspiration and less resistance or-obstruction to breathing is therefore present in this phase of breathing than in the expiratory cycle. In the present study the added resistance to breathing remained constant during both phases of respiration and therefore a pathologic intrabronchial obstruction to breathing is not entirely reproduced.

In animal experiments it has been shown by Moore and Binger $(4,5)$ and Barach $(6-8)$ that obstructed breathing either during inspiration or both phases of respiration results in pulmonary congestion and intra-alveolar edema. These changes were not found when a comparable resistance to breathing was maintained during expiration only. The pathological consequences of obstructive breathing were therefore attributed to the abnormally lowered pressure exerted on the lungs during inspiration. The sequelae of obstructive respiration appear to be traced to the effect of increased negative pressure on pulmonary capillaries, production of mucus from the bronchial mucous membrane, an increased output of the right heart, and a diminished output from the left heart. In cases of severe bronchial asthma, a 
pathologically lowered negative intrapleural pressure during inspiration has also been demonstrated by Barach (16).

Maloney and Whittenberger (17) and Beck, Seanor and Barach (18) have shown that the physiological effects of negative pressure surrounding the body in a tank respirator are comparable to those produced by positive pressure applied at the mouth and nose. This relationship had already been pointed out by Henderson (19). The mechanism of exsufflation, therefore, includes inspiratory positive pressure breathing, which is mainly comparable to positive pressure breathing produced in other ways. In studies by Motley and his co-workers $(20,21)$ on intermittent positive pressure breathing it was found that the type III curve with a low mean pressure and a rather rapid return to atmospheric pressure in expiration was the respirator of choice. However, in the type III curve expiration lasts 1.11 seconds and the return to atmosphere takes place in approximately 0.5 seconds. In exsufflation the mean applied pressure is $5.5 \mathrm{~cm} . \mathrm{H}_{2} \mathrm{O}$ and expiration, except for the first 0.06 seconds, takes place at atmospheric pressure. The relaxation pressure of the lungs, therefore, operates more effectively during the greater part of the expiratory cycle. Furthermore, the relative absence of increased intrapulmonary pressure during the expiratory cycle of exsufflation permits the use of high ventilatory pressures with minimal effect on the circulation. Since the effect on cardiac output has been shown to depend on the mean applied intrapulmonary pressure (14) and rapidity of drop of expiration pressure $(20,21)$, exsufflation with its low mean pressure and rapid drop of pressure at the beginning of expiration probably has little effect on the mean output of the heart.

The introduction of a resistance to breathing, resulting in increased inspiratory and expiratory effort produces physiological effects comparable to negative pressure breathing in inspiration and positive pressure breathing in expiration. The addition of inspiratory positive pressure by exsufflation more than compensates for the inspiratory negative pressure breathing, and inspiration now takes place under positive pressure. Since with exsufflation expiration (except for the first 0.06 seconds) takes place at atmospheric pressure, the relaxation pressure of the lungs during this procedure overcomes the effect of resistance to air flow during the expiratory cycle. Thus, exsufflation during obstructed breathing results in positive pressure breathing during both phases of respiration.

It has been demonstrated $(1,2)$ that the inspiratory flow rate is less frequently disturbed in obstructed breathing than is that of expiration. In our studies, peak volume flow rate decreased 15 per cent during inspiration and 29 per cent during expiration. The alteration of volume flow rate produced by exsufflation was most strikingly manifested in inspiration. The expiratory volume flow rate was increased particularly at the onset of expiration. The major action of exsufflation on the volume flow rate during inspiration is explained by the fact that air is being introduced into the lungs under positive pressure. The increased flow rate at the onset of expiration can be attributed to the rapid elimination of the negative pressure surrounding the chest, allowing the relaxation pressure of the lungs and surrounding tissues to operate promptly and at its fullest extent.

In current studies by Bickerman, Beck and Barach (22) the diameters of medium-sized bronchi of dogs are increased two-fold at the peak of the $40 \mathrm{~mm}$. Hg pressure. With the abrupt termination of this pressure there is a rapid contraction and shortening of the entire bronchial tree, which is a factor in the production of the high volume flow rate seen especially at the onset of expiration.

The advantageous effect of exsufflation in relieving the hypercapnia and hypoxia which develop during obstructed breathing is clearly demonstrated. Exsufflation would appear to be of special value in patients with pulmonary emphysema who have developed respiratory acidosis, since it would provide an effective method of restoring to normal the altered $\mathrm{CO}_{2}$ and $\mathrm{O}_{2}$ tensions present in this syndrome.

Cain and Otis (1) have shown that the total ventilation decreases while breathing against an added resistance. In our studies the fall in tidal volume and minute ventilation during obstructive breathing was markedly reversed by the addition of exsufflation. The rise in oxygen tension during exsufflation despite a rate of only nine times a minute must be due to a more effective alveolar ventilation. Since the rate of exsufflation can be 
controlled, any desired increase in minute ventilation can easily be achieved without the high mean intrapulmonary pressures produced by conventional forms of pressure breathing, where there is ventilation with a gradually descending expiratory pressure curve.

The marked drop in peripheral venous pressure and intraoral pressure during the inspiratory phase of obstructed breathing is overcome by exsufflation and there is at no time the development of lowered intraoral or peripheral venous pressure. Assuming that intraoral and peripheral venous pressure are reflections of intrathoracic pressures, an abnormally lowered negative intrapleural pressure is present during the inspiratory phase of obstructed breathing, and a reversal of this state takes place with the addition of exsufflation. A reduction in the height of negative intrapleural pressure by the application of pressure breathing has also been shown by Barach (7) in experimentally induced obstructive dyspnea in dogs and in a patient with severe bronchial asthma. He also showed that as the intrapleural pressure became more negative, pulmonary congestion developed, and that anything that decreased the negative intrapleural pressure would tend to decrease the likelihood of development of congestion. Since obstructed breathing over a prolonged period of time will result in pulmonary congestion, the physiologic action of exsufflation in reversing the lowered venous pressure and presumably the lowered intrapleural pressure would appear to prevent the consequences of obstructive dyspnea and thus be useful in clinical entities characterized by obstructive lesions in the respiratory tract.

\section{SUM MARY}

Obstructive respiration was produced in normal human subjects by breathing through a $3 \mathrm{~mm}$. orifice. Marked subjective dyspnea was accompanied by the following pathophysiological consequences : 1) A diminution of inspiratory and expiratory volume flow rates; 2) An elevation of alveolar $\mathrm{pCO}_{2}$ and lowering of $\left.\mathrm{pO}_{2} ; 3\right)$ A lowering of peripheral venous pressure; and 4) $\mathrm{A}$ marked decrease in inspiratory intraoral pressure.

Exsufflation consists of inflation of the lungs with a $40 \mathrm{~mm}$. $\mathrm{Hg}$ pressure and a rapid termination of the pressure at the onset of the expiratory cycle. When this mechanism was applied during obstructed breathing, subjective dyspnea was relieved and the physiological alterations noted were reversed towards normal levels. The beneficial effect of exsufflation can be attributed to $(a)$ inspiratory positive pressure breathing, and (b) the prompt and effective use of the increased relaxation pressure of the lungs.

The restoration towards normal of physiologic consequences of experimentally induced obstructed breathing suggests that the use of the mechanism of exsufflation would be of therapeutic value in those clinical conditions characterized by obstructive lesions in the respiratory tract.

\section{REFERENCES}

1. Cain, C. C., and Otis, A. B., Some physiological effects resulting from added resistance to respiration. J. Aviation Med., 1949, $20,149$.

2. Proctor, D. F., Hardy, J. B., and McLean, R., Studies of respiratory air flow. II. Observations on patients with pulmonary disease. Bull. Johns Hopkins Hosp., 1950, 87, 255.

3. Haldane, J. S., and Priestley, J. G., Respiration, New ed. New Haven, Yale University Press, 1935, p. 311.

4. Moore, R. L., and Binger, C. A. L., Observations on resistance to the flow of blood to and from the lungs. J. Exper. Med., 1927, 45, 655.

5. Moore, R. L., and Binger, C. A. L., The response to respiratory resistance: A comparison of the effects produced by partial obstruction in the inspiratory and expiratory phases of respiration. J. Exper. Med., 1927, 45, 1065.

6. Barach, A. L., The effects of inhalation of helium mixed with oxygen on the mechanics of respiration. J. Clin. Invest., 1936, 15, 47.

7. Barach, A. L., The therapeutic use of helium. J.A. M.A., 1936, 107, 1273.

8. Barach, A. L., Martin, J., and Eckman, M., Positive pressure respiration and its application to the treatment of acute pulmonary edema. Ann. Int. Med., 1938, 12, 754.

9. Barach, A. L., Beck, G. J., Bickerman, H. A., and Seanor, H. E., Mechanical coughing: Studies on physical methods of producing high velocity flow rates during the expiratory cycle. Tr. A. Am. Physicians., 1951, 64, 360.

10. Barach, A. L., Beck, G. J., Bickerman, H. A., and Seanor, H. E., Physical methods of simulating a human cough. To be published.

11. Barach, A. L., Bickerman, H. A., and Beck, G. J., Advances in the treatment of non-tuberculous pulmonary disease. Bull. New York Acad. Med., 1952, 28, 353.

12. Barach, A. L., Eckman, M., Ginsburg, E., Rumsey, C. C., Korr, I., Eckman, I., and Besson G., Studies on positive pressure respiration. I. General 
aspects and types of pressure breathing. II. Effects on respiration and circulation at sea level. J. Aviation Med., 1946, 17, 290.

13. Otis, A. B., Rahn, H., and Fenn, W. O., Venous pressure changes associated with positive intrapulmonary pressures; their relationship to the distensibility of the lung. Am. J. Physiol., 1946, 146, 307.

14. Barach, A. L., Fenn, W. O., Ferris, E. B., and Schmidt, C. F., The physiology of pressure breathing. J. Aviation Med., 1947, 18, 73.

15. Elisberg, E. I., Goldberg, H., and Snider, G. L., Value of intraoral pressure as a measure of intrapleural pressure. J. Appl. Physiol., 1951, 4, 171.

16. Barach, A. L., Physiologic Therapy in Respiratory Diseases, 2d ed., Philadelphia, J. B. Lippincott, 1948, p. 122.

17. Maloney, J. V., and Whittenberger, J. L., Clinical implications of pressures used in the body respirator. Am. J. M. Sc., 1951, 221, 425.
18. Beck, G. J., Seanor, H. E., and Barach, A. L., Effects of pressure breathing on venous pressure; A comparative study of positive pressure applied to the upper respiratory passageway and negative pressure to the body of normal individuals. Am. J. M. Sc., 1952, 224, 169.

19. Henderson, Y., Adventures in Respiration, Baltimore, Williams \& Wilkins Co., 1938, p. 272.

20. Motley, H. L., Werko, L., Cournand, A., and Richards, D. W., Jr., Observations on the clinical use of intermittent positive pressure. J. Aviation Med., 1947, 18, 417.

21. Motley, H. L., Cournand, A., Werko, L., Dresdale, D. T., Himmelstein, A., and Richards, D. W., Jr., Intermittent positive pressure breathing. A means of administering artificial respiration in man. J.A. M.A., 1948, 137, 370.

22. Bickerman, H. A., Beck, G. J., and Barach, A. L., Physical methods of eliminating radiopaque material from the bronchi of dogs. To be published. 